\title{
AUTHORS
}

\section{Rishi Agrawal, MD, MPH}

Pediatric Hospitalist, Children's Memorial Hospital and LaRabida Children's Hospital

Assistant Professor of Pediatrics, Northwestern University Feinberg School of Medicine

Chicago, IL

Feeding Tubes

Brian Alverson, MD

Head, Pediatric Hospitalist Section, Hasbro Children's Hospital

Assistant Professor of Pediatrics, Warren Alpert School of Medicine at Brown University

Providence, RI

Neonatal Fever

Pneumonia

\section{Allison Ballantine, MD}

Medical Director of the Integrated Care Service, Children's Hospital of Philadelphia

Assistant Professor of Pediatrics, University of Pennsylvania School of Medicine

Philadelphia, PA

Technology Dependent Children

\section{Julia Beauchamp-Walters, MD}

Pediatric Emergency Transport Coordinator, CSSD, RCHHC Pediatric Emergency Transports,

Rady Childrens Hospital

Clinical Instructor of Pediatrics, University of California, San Diego

San Diego, CA

Transport of the Critically Ill Child

\section{Glenn F. Billman, MD}

Medical Safety and Regulatory Officer, Rady Children's Hospital

San Diego, CA

Patient Safety

April O. Buchanan, MD, FAAP

Vice Chair of Quality, Department of Pediatrics, Children's Hospital at Greenville Hospital System University Medical Center

Assistant Professor of Clinical Pediatrics, University of South Carolina School of Medicine

Greenville, SC

Shock

Douglas W. Carlson, MD

Chief, Pediatric Hospital Medicine, St. Louis Children's Hospital Associate Professor of Pediatrics, Washington University

St. Louis, MO

Procedural Sedation

Technology Dependent Children

\section{Vincent W. Chiang, MD}

Chief, Inpatient Services, Department of Medicine, Children's Hospital Boston

Associate Professor of Pediatrics, Harvard Medical School

Boston, MA

Seizures

Michael R. Clemmens, MD

Director Pediatric Hospitalist Program, Anne Arundel Medical Center

Assistant Clinical Professor of Pediatrics, The George Washington University School of Medicine Annapolis, MD

Acute Abdominal Pain and The Acute Abdomen

\section{Jamie L. Clute, MD, FAAP, FHM}

Medical Director, Inpatient Services, Joe Dimaggio Children's Hospital

Clinical Assistant Professor, NOVA Southeastern University, College of Osteopathic Medicine and

Assistant Affiliate Professor, Barry University

Hollywood, FL

Kawasaki Disease 
Shannon Connor Phillips, MD, MPH

Patient Safety Officer, Quality and Patient Safety Institute, Cleveland Clinic

Assistant Professor of Pediatrics, Cleveland Clinic Lerner College of Medicine at

Case Western Reserve University

Cleveland, $\mathrm{OH}$

Evidence Based Medicine

Tanya Dansky, MD

Medical Director, Children's Physicians Medical GroupMedical Director, San Diego Hospice and The Institute For Palliative Medicine, Rady Children's Hospital

Assistant Clinical Professor of Pediatrics, University of California, San Diego

San Diego, CA

Hospice and Palliative Care, Ethics

\section{Jennifer Daru, MD, FAAP, FHM}

Chief, Pediatric Hospitalist Division; Interim Chief, Pediatric and Neonatal Transport, California Pacific Medical Center

Clinical Assistant Professor (pending), University of California San Francisco

San Francisco, CA

Leading a Healthcare Team

Newborn Care and Delivery Room Management

\section{Yasmeen N. Daud, MD}

Director of Pediatric Hospitalist Sedation in the Pediatric Acute Wound Service and Director of the Pediatric

Hospitalist After Hours Sedation Program, St. Louis Children's Hospital

Assistant Professor of Pediatrics, Washington University School of Medicine

St. Louis, MO

Oxygen Delivery and Airway Management

\section{Craig DeWolfe, MD, MEd}

Pediatric Hospitalist, Children's National Medical Center

Assistant Professor of Pediatrics, George Washington School of Medicine and Health Sciences

Washington DC

Apparent Life-Threatening Event

\section{Joseph M. Geskey, DO}

Division Chief, Pediatric Hospital Medicine, Medical Director of Hospital Care Management,

Penn State Hershey Children's Hospital

Associate Professor of Pediatrics, Penn State M. S. Hershey Medical Center

Hershey, PA

Pneumonia

Upper Airway Infections

Bronchiolitis

Paul D. Hain, MD

Associate Chief of Staff, Monroe Carell Jr. Children's Hospital at Vanderbilt

Assistant Professor of Pediatrics, Vanderbilt University

Nashville, TN

Health Information Systems

\section{Keith Herzog, MD}

Pediatric Hospitalist, St. Christopher's Hospital for Children

Assistant Professor of Pediatrics, Drexel University College of Medicine

Philadelphia, PA

Central Nervous System Infections

\section{Margaret Hood, MD, FAAP}

Pediatric Hospitalist, Seattle Children's Hospital

Clinical Associate Professor of Pediatrics, University of Washington

Seattle, WA

Diabetes Mellitus

Hospice and Palliative Care

\section{Kevin B. Johnson, MD, MS}

Vice Chair of Biomedical Informatics, Vanderbilt University Medical Center Associate Professor of Medical Informatics and Pediatrics, Vanderbilt University Medical Center Nashville, TN

Health Information Systems 


\section{Rick Johnson, MD, FAAP}

Division Head, Regional Pediatrics, CCMC, and American Heart Association Regional and National PALS

Faculty, Connecticut Children's Medical Center

Assistant Professor of Pediatrics, University of Connecticut School of Medicine

Hartford, CT

Pediatric Advanced Life Support

\section{Brian Kelly, MD, MRCP (UK), FAAP}

Pediatric Hospitalist, Ranken Jordan Pediatric Rehabilitative Hospital, St. Louis Children's Hospital Assistant Professor of Pediatrics, Washington University School of Medicine

St. Louis, MO

Bladder Catheterization/Suprapubic Bladder Tap

\section{Herbert C Kimmons, MD, MMM}

President Children's Specialists of San Diego (Medical Quality Officer of Rady Children's Hospital of San Diego, 2006-2008), Children's Specialists of San Diego in California

Professor of Pediatrics, University of California San Diego

San Diego, CA

Continuous Quality Improvement

Patient Safety

\section{Su-Ting T. Li, MD, MPH}

Associate Pediatric Residency Program Director, University of California, Davis Assistant Professor of Pediatrics, University of California, Davis

Sacramento, CA

Skin and Soft Tissue Infections

\section{Patricia S. Lye, MD}

Medical Director, Hospitalists, Children's Hospital of Wisconsin Associate Professor of Pediatrics, Medical College of Wisconsin Milwaukee, WI

Transitions of Care

\section{Jennifer Maniscalco, MD, MPH, FAAP}

Director of Education, Division of Pediatric Hospital Medicine, Children's Hospital Los Angeles Clinical Assistant Professor of Pediatrics, University of Southern California Keck School of Medicine Los Angeles, CA Failure to Thrive Transitions of Care Nutrition

\section{David E. Marcello III, MD, FAAP}

Pediatric Hospitalist, Connecticut Children's Medical Center Assistant Professor in Pediatrics, University of Connecticut Medical School Hartford, CT Lumbar Puncture Intravenous Access and Phlebotomy

\section{Sanford M. Melzer, MD, MBA}

Senior Vice President, Strategic Planning and Business Development, Seattle Children's Hospital Professor of Pediatrics, University of Washington School of Medicine Seattle, WA Cost Effective Care

\section{Margaret I. Mikula, MD}

Pediatric Hospitalist, Penn State Hershey Children's Hospital Assistant Professor of Pediatrics, Penn State M. S. Hershey Medical Center Hershey, PA

Pneumonia

Bronchiolitis

\section{Laura J Mirkinson, MD, FAAP}

Director of Pediatrics, Blythedale Children's Hospital

Valhalla, NY

Neonatal Jaundice 
Christopher D. Miller, MD, FAAP

Pediatric Hospitalist and Allergist, Children's Mercy Hospitals and Clinics

Assistant Professor of Pediatrics, University of Missouri-Kansas City School of Medicine

Kansas City, MO

Asthma

\section{Christopher O'Hara, MD, FACP}

St. Christopher's Hospital for Children

Assistant Professor of Pediatrics, Drexel University College of Medicine

Philadelphia PA

Pain Management

\section{Mary C. Ottolini MD, MPH, FAAP, FHM}

Chair, Academic Pediatric Association Education Committee

Immediate Past Hospitalist Division Chief; Vice Chair for Medical Education, Children's National Medical Center

Professor of Pediatrics, The George Washington University School of Medicine

Washington DC

Fluid and Electrolyte Management

Gastroenteritis

Education

\section{Brian M. Pate, MD, FAAP, FHM}

Section Chief, Pediatric Hospital Medicine, Vice Chairman, Inpatient Services, Children's Mercy Hospital and Clinics Assistant Professor of Pediatrics, University of Missouri-Kansas City School of Medicine

Business Practices

Asthma

\section{Dana Patrick, RN, BSN}

Transport Program Manager NICUPICU, Rady Children's Hospital

San Diego, CA

Transport of the Critically Ill Child

\section{Jack M. Percelay, MD, MPH, FAAP, FHM}

Society of Hospital Medicine, Pediatric Board Member; Immediate Past-Chair, AAP Section on

Hospital Medicine, E.L.M.O. Pediatrics

Associate Professor, Pace University Physician Assistant Program

New York, New York

Advocacy

\section{David Pressel, MD, PhD, FHM, FAAP}

Director, General Pediatrics Inpatient Services, A.I. duPont Hospital for Children Assistant Professor of Pediatrics, Jefferson Medical College, Thomas Jefferson University Wilmington, DE

Child Abuse and Neglect

\section{Kris P Rehm, MD}

Director, Division of Hospital Medicine, Monroe Carell Jr Children's Hospital at Vanderbilt Assistant Professor of Pediatrics, Vanderbilt University

Nashville, TN

Respiratory Failure

\section{Kyung E. Rhee, MD, MSc}

Pediatric Hospitalist, Hasbro Children's Hospital and The Weight Control and Diabetes Research Center Assistant Professor of Pediatrics, Warren Alpert Medical School of Brown University

Providence, RI

Fever of Unknown Origin

\section{Mark F Riederer, MD}

Pediatric Hospitalist, Monroe Carell Jr Children's Hospital at Vanderbilt

Assistant Professor of Pediatrics,

Nashville, TN

Respiratory Failure

\section{Michael Ruhlen, MD, MHCM, FAAP, FHM, FACHE}

Vice President and Chief Medical Officer, Carolinas Medical Center - Mercy

Carolinas Medical Center - Pineville

Charlotte, NC

Legal Issues/Risk Management 


\section{Henry M. Seidel, MD}

Professor Emeritus, Johns Hopkins Berman Institute of Bioethics

Professor Emeritus of Pediatrics, The Johns Hopkins University School of Medicine

Baltimore, MD

Communication

\section{Anand Sekaran, MD}

Medical Director, Inpatient Services, Connecticut Children's Medical Center Assistant Professor of Pediatrics, University of Connecticut School of Medicine Hartford, CT

Radiographic Interpretation

\section{Kristin A. Shadman, MD, FAAP}

Pediatric Hospitalist

Oxygen Delivery and Airway Management

\section{Vipul Singla, MD, FAAP}

Site Leader, Lake Forest Hospital (Children's Memorial Medical Group) Instructor in Pediatrics, Northwestern University Feinberg School of Medicine Chicago, IL

Electrocardiogram Interpretation

\section{Karen Smith, MD, MEd}

Chief Medical Officer, The HSC Pediatric Center Assistant Professor of Pediatrics, The George Washington University School of Medicine Washington DC

Apparent Life-Threatening Event

\section{Jeffrey L. Sperring, MD}

Chief Medical Officer, Riley Hospital for Children Assistant Professor of Pediatrics, Indiana University School of Medicine Indianapolis, IN

Bone and Joint Infections

\section{Glenn Stryjewski, MD, MPH}

Associate Residency Program Director, AI duPont Hospital for Children Assistant professor of Pediatrics, Jefferson Medical College, Thomas Jefferson University Wilmington, DE

Toxic Ingestion

\section{Erin R. Stucky, MD, FAAP, FHM}

Director of Graduate Medical Education, Rady Children's Hospital San Diego; Medical Director of Quality Improvement, Rady Children's Hospital San Diego; Associate Program Director, UCSD Pediatric Residency Program; Vice Chair for Clinical Affairs, UCSD Department of Pediatrics; Director, Pediatric Hospital Medicine Fellowship, Rady Children's Hospital Clinical Professor of Pediatrics, University of California San Diego San Diego, CA

Evidence Based Medicine Continuous Quality Improvement

Technology Dependent Children

\section{E. Douglas Thompson, Jr., MD}

Director, Pediatric Generalist Service, St. Christopher's Hospital for Children Assistant Professor of Pediatrics, Drexel University College of Medicine Philadelphia, PA

Sickle Cell Disease

\section{Michael Turmelle, MD}

Pediatric Hospitalist, St. Louis Children's Hospital Assistant Professor of Pediatrics, Washington University School of Medicine St. Louis, MO

Non-Invasive Monitoring 
Macdara G. Tynan, MD, MBA, FAAP

Associate Director of Inpatient Pediatrics, Levine Children's Hospital

Charlotte, NC

Diabetes Mellitus

Toxic Ingestion

\section{Ronald J. Williams, MD}

Pediatric Hospitalist, Penn State Hershey Children's Hospital

Associate Professor of Pediatrics and Medicine, Penn State M. S. Hershey Medical Center

Hershey, PA

Upper Airway Infections

\section{Heidi Wolf MD, FAAP}

Director Pediatric Hospitalist Program, Johns Hopkins

Assistant Clinical Professor, John Hopkins University

Baltimore, MD

Fever of Unknown Origin

Neonatal Fever

\section{Susan Wu, MD}

Pediatric Hospitalist, Children's Hospital Los Angeles

Clinical Assistant Professor of Pediatrics, University of Southern California Keck School of Medicine

Los Angeles, CA

Bronchiolitis

Lisa B. Zaoutis, MD

Section Chief of Inpatient Services, Division of General Pediatrics, The Children's Hospital of Philadelphia Assistant Professor of Pediatrics, University of Pennsylvania School of Medicine

Philadelphia, PA

Urinary Tract Infections

\section{William T. Zempsky, MD}

Associate Director; Division of Pain Medicine; Department of Pediatrics, Associate Director, Pain Relief Program, Connecticut Children's Medical Center

Professor of Pediatrics, University of Connecticut School of Medicine

Hartford, CT

Pain Management

\section{REVIEWERS}

\section{Allison Ballantine, MD}

Medical Director of the Integrated Care Service, Children's Hospital of Philadelphia

Assistant Professor of Pediatrics, University of Pennsylvania School of Medicine

Philadelphia, PA

Technology Dependent Children

\section{Margaret Hood, MD, FAAP}

Pediatric Hospitalist, Seattle Children's Hospital

Clinical Associate Professor of Pediatrics, University of Washington

Seattle, WA

Hospice and Palliative Care

Ethics

\section{Brian Kit, MD, MPH}

Anne Arundel Medical Center

Assistant Professor of Pediatrics, The George Washington University School of Medicine

Annapolis, MD

Advocacy

\section{Evelina M. Krieger, MD}

Children's National Medical Center

Assistant Professor of Pediatrics, The George Washington University School of Medicine

Washington, DC

Advocacy 
Cynthia L. Kuelbs, MD

Medical Director, Chadwick Center for Child Abuse; Division Director Pediatric Hospital Medicine,

Rady Children's Hospital

Associate Clinical Professor of Pediatrics, University of California San Diego

San Diego, CA

Child Abuse and Neglect

\section{Christopher P. Landrigan, MD, MPH}

Division Director, Pediatrics and Hospital Medicine; Research and Fellowship Director,

Children's Hospital Boston Inpatient Pediatrics Service; Director,

Sleep and Patient Safety Program at the Brigham and Women's Hospital,

Children's Hospital Boston

Assistant Professor of Pediatrics and Medicine, Harvard Medical School

Boston, MA

Research

\section{Michael Ruhlen, MD, MHCM, FAAP, FHM, FACHE}

Vice President and Chief Medical Officer, Carolinas Medical Center - Mercy

Carolinas Medical Center - Pineville

Charlotte, $\mathrm{NC}$

Legal Issues/Risk Management

\section{Samir S. Shah, MD, MSCE}

Senior Scholar, Center for Clinical Epidemiology and Biostatistics, The Children's Hospital of Philadelphia Assistant Professor, Departments of Pediatrics and Biostatistics and Epidemiology, University of Pennsylvania School of Medicine Philadelphia, PA

Research

\section{Rajendu Srivastava, MD, FRCP(C), MPH}

Director of Pediatric Research in the Inpatient Setting (PRIS) Network,

Primary Children's Medical Center, Intermountain Healthcare Inc.

Associate Professor, Division of Inpatient Medicine, Department of Pediatrics,

University of Utah Health Sciences Center

Salt Lake City, UT

Research

\section{Ben Bauer, MD, FAAP}

Pediatric Hospital Medicine; Fellowship Director, Riley Children's Hospital, Indiana University School of Medicine Indianapolis, IN

\section{John Combes, MD}

President/COO, Center for Healthcare Governance, American Hospital Association (AHA)

Washington, DC

\section{Jennifer Daru, MD, FAAP, FHM}

Chair-elect AAP; Section on Hospital Medicine, American Academy of Pediatrics

San Francisco, CA

Jerrold Eichner, MD, FAAP

Chair, AAP National Committee on Hospital Care, American Academy of Pediatrics

Great Falls, MT

\section{Rosemarie Faber, MSN/ED, RN, CCRN}

Clinical Practice Specialist, American Association of Critical Care Nurses

Aliso Viejo, CA

\section{Rani S Gereige, MD, MPH, FAAP}

Director of Medical Education, Miami Children's Hospital

Miami, FL

\section{David Jaimovich, MD, FAAP}

President, QRI (Former Chief Medical Officer and Vice President for International Accreditation Services for Joint Commission Resources (JCR) and Joint Commission International (JCI)), Quality Resources International

\section{Andrea Kline RN, MS, CPNP-AC, CCRN, FCCM}

Executive Board; Professional Issues; Pediatric Critical Care NP, National Association of Pediatric Nurse Practitioners (NAPNAP)

Cherry Hill, NJ 
David D. Lloyd, MD, FRCP(C), FAAP

Section Chief of General Pediatrics Children's Healthcare of Atlanta,

Director of Undergraduate Pediatric Education, Director of the Pediatric Hospitalist Fellowship,

Children's Healthcare of Atlanta, Emory University School of Medicine

Atlanta, GA

Patricia S. Lye, MD, FAAP

AAP Section on Hospital Medicine, American Academy of Pediatrics

Milwaukee, WI

\section{Sanjay Mahant, MD, FRCPC}

Pediatric Hospital Medicine Fellowship Director, Hospital for Sick Children, University of Toronto School of Medicine

Toronto, Canada

\section{Jennifer Maniscalco, MD, MPH, FAAP}

Pediatric Hospital Medicine Fellowship Director, Children's Hospital Los Angeles

University of Southern California School of Medicine

\section{Marlene Miller, MD, MSc, FAAP}

Vice President for Quality, National Association of Children's Hospitals and Related Institutions (NACHRI) Alexandria, VA

Paul E. Manicone, MD, FAAP

Associate Division Chief; Division of Hospitalist Medicine; Immediate past Fellowship Director, Children's National Medical Center, George Washington University School of Medicine Washington DC

\section{Warren Newton, MD}

American Board of Family Medicine Board of Directors: Research and Development, IT, and Communications/publications Committees; Executive Associate Dean for Medical Education and William B. Aycock Distinguished Professor and Chair, Department of Family Medicine at the University of North Carolina at Chapel Hill, American Board of Family Medicine

Lexington, $\mathrm{KY}$

\section{Daniel Rauch, MD, FAAP, FHM}

Chair, AAP Section on Hospital Medicine; Immediate Past Chair, Academic Pediatric Association Hospital Medicine Special Interest Group AAP and APA

\section{Ellen Schwalenstocker, PhD, MBA}

Quality, Advocacy and Measurement, NACHRI

Alexandria, VA

Mary Jean Schuman, MSN, MBA, RN, CPNP

Chief Programs Officer, American Nursing Association

Silver Spring, MD

\section{Neha H. Shah, MD, FAAP}

Fellowship Director, Pediatric Hospital Medicine, Children's National Medical Center

George Washington University School of Medicine

Washington, DC

\section{Geeta Singhal, MD, FAAP}

Director, Pediatric Hospital Medicine Fellowship; Director, Faculty Inpatient Service; Co-Director, PEM Faculty Development Program, Texas Children's Hospital, Baylor College of Medicine

Houston, TX

\section{Jeffrey L. Sperring, MD, FAAP}

Chair, Academic Pediatric Association Hospital Medicine Special Interest Group

Chief Medical Officer, Academic Pediatric Association

Indianapolis, IN

\section{Erin R. Stucky, MD, FAAP, FHM}

Pediatric Hospital Medicine, Fellowship Director, Rady Children's Hospital San Diego

University of California San Diego School of Medicine

San Diego, CA 


\section{EDITORS}

Michael G. Burke, MD, MBA

Chairman of Pediatrics, Saint Agnes Hospital

Assistant Professor of Pediatrics, The Johns Hopkins University School of Medicine

Baltimore, MD

Douglas W. Carlson, MD

Chief, Pediatric Hospital Medicine, St. Louis Children's Hospital

Associate Professor of Pediatrics, Washington University

St. Louis, MO

Timothy T. Cornell, MD

C. S. Mott Women and Children's Hospital

Assistant Professor in the Department of Pediatrics and Communicable Diseases, University of Michigan Ann Arbor, MI

Jack M. Percelay, MD, MPH, FAAP, FHM

Society of Hospital Medicine, Pediatric Board Member; Immediate Past-Chair, AAP Section on Hospital Medicine, E.L.M.O. Pediatrics

Associate Professor, Pace University Physician Assistant Program

New York, New York

\section{Daniel Rauch, MD, FAAP, FHM}

Associate Director of Pediatrics, Elmhurst Hospital New York

Anand Sekaran, MD

Medical Director, Inpatient Services, Connecticut Children's Medical Center

Assistant Professor of Pediatrics, University of Connecticut School of Medicine

Hartford, CT

\section{E. Douglas Thompson, Jr., MD}

Director, Pediatric Generalist Service, St. Christopher's Hospital for Children

Assistant Professor of Pediatrics, Drexel University College of Medicine

Philadelphia, PA

\section{Heidi Wolf MD, FAAP}

Director Pediatric Hospitalist Program, Johns Hopkins

Assistant Clinical Professor, John Hopkins University

Baltimore, MD

\section{David Zipes, MD FAAP, FHM}

Director, St. Vincent Pediatric Hospitalists, Peyton Manning Children's Hospital at St. Vincent Indianapolis, IN

\section{SENIOR EDITORS}

\section{Jennifer Maniscalco, MD, MPH, FAAP}

Director of Education, Division of Pediatric Hospital Medicine, Children's Hospital Los Angeles Clinical Assistant Professor of Pediatrics, University of Southern California Keck School of Medicine Los Angeles, CA

\section{Mary C. Ottolini MD, MPH, FAAP, FHM}

Chair, Academic Pediatric Association Education Committee

Immediate Past Hospitalist Division Chief; Vice Chair for Medical Education, Children's National Medical Center Professor of Pediatrics, The George Washington University School of Medicine

Washington DC

\section{Erin R. Stucky, MD, FAAP, FHM}

Director of Graduate Medical Education, Rady Children's Hospital San Diego;

Medical Director of Quality Improvement, Rady Children's Hospital San Diego;

Associate Program Director, UCSD Pediatric Residency Program;

Vice Chair for Clinical Affairs, UCSD Department of Pediatrics;

Director, Pediatric Hospital Medicine Fellowship, Rady Children's Hospital

Clinical Professor of Pediatrics, University of California San Diego

San Diego, CA 